\title{
THE DARELLS OF CALEHILL: CONFUSED AND CONFLICTING RELIGIOUS LOYALTIES IN SIXTEENTH AND SEVENTEENTH CENTURY ENGLAND
}

\author{
by Elizabeth M. STrudwick*
}

$\mathrm{T}$ he Darell family history provides a good illustration of the confused and conflicting religious loyalties in sixteenth and seventeenth century England. There were four branches of the family in southern England, all originally descended from William Darrell of Sesay, Yorkshire, in the early fifteenth century. The Pagham and Fulmere branches descended from William of Littlecote; the Calehill branch from John of Calehill by his first wife; and the Scotney branch from John of Calehill by his second wife, niece and heiress of Archbishop Chichele, who owned Scotney Castle. In this paper I am mainly concerned with the Calehill branch. Burton, in his life of Bishop Challoner, stated 'they were always Catholics' and he was followed by McGurk, ${ }^{1}$ but the head of the Calehill branch was not in fact a recusant until after 1694. From that time they were consistently Catholic.

\section{Protestant Darrells}

The head of the Calehill family in 1535 was Sir George Darell, who succeeded his father Sir James in 1525 and died in $1583 .^{2} \mathrm{He}$ and his brother Hugo were considered suitable in 1564 to hold office as Justices of the Peace, being, according to Archbishop Parker, 'in favourable affection toward the state of religion... outwardly conformable and not chargeable to my knowledge of any great extremities uttered by them in afflicting the honest and godly or in maintaining the perverse and ungodly'. ${ }^{3}$ This may not imply a fervent Protestantism, but clearly they did not stand out as Catholics, as did, for instance, Sir Edward Gage of Firle and Mr. Thomas Culpeper of Ardingly in William Barlow's list of Chichester Justices.

Sir George's eldest son John married Anna, ${ }^{4}$ daughter of Robert Horne who had fled to Frankfurt in Queen Mary's reign and was one of Queen

\footnotetext{
${ }^{*}$ The late Mrs. Elizabeth Strudwick incorporates some of the earlier material from Kent Recusant History in the 1980s and permission to use the material is gratefully acknowledged.
} 


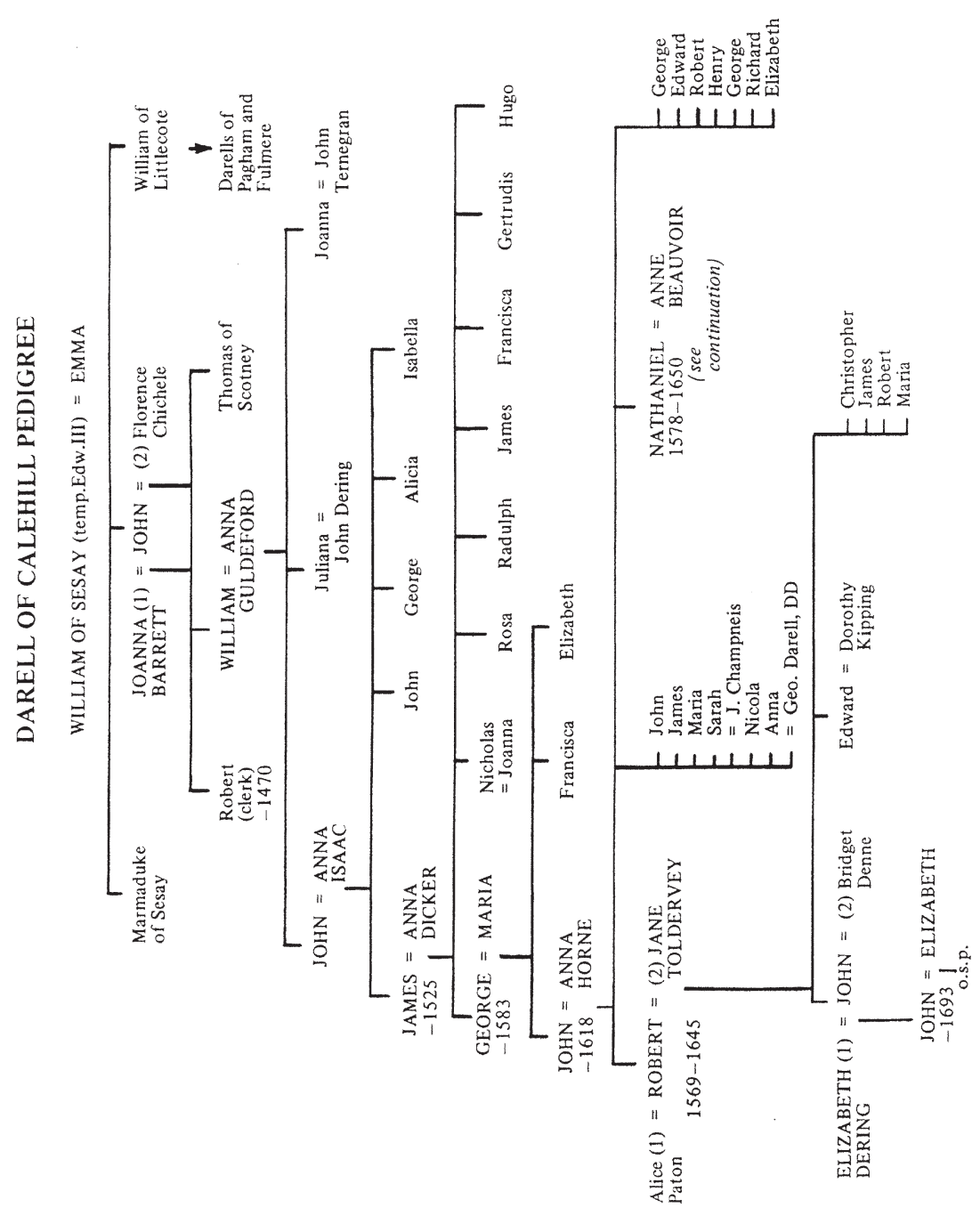




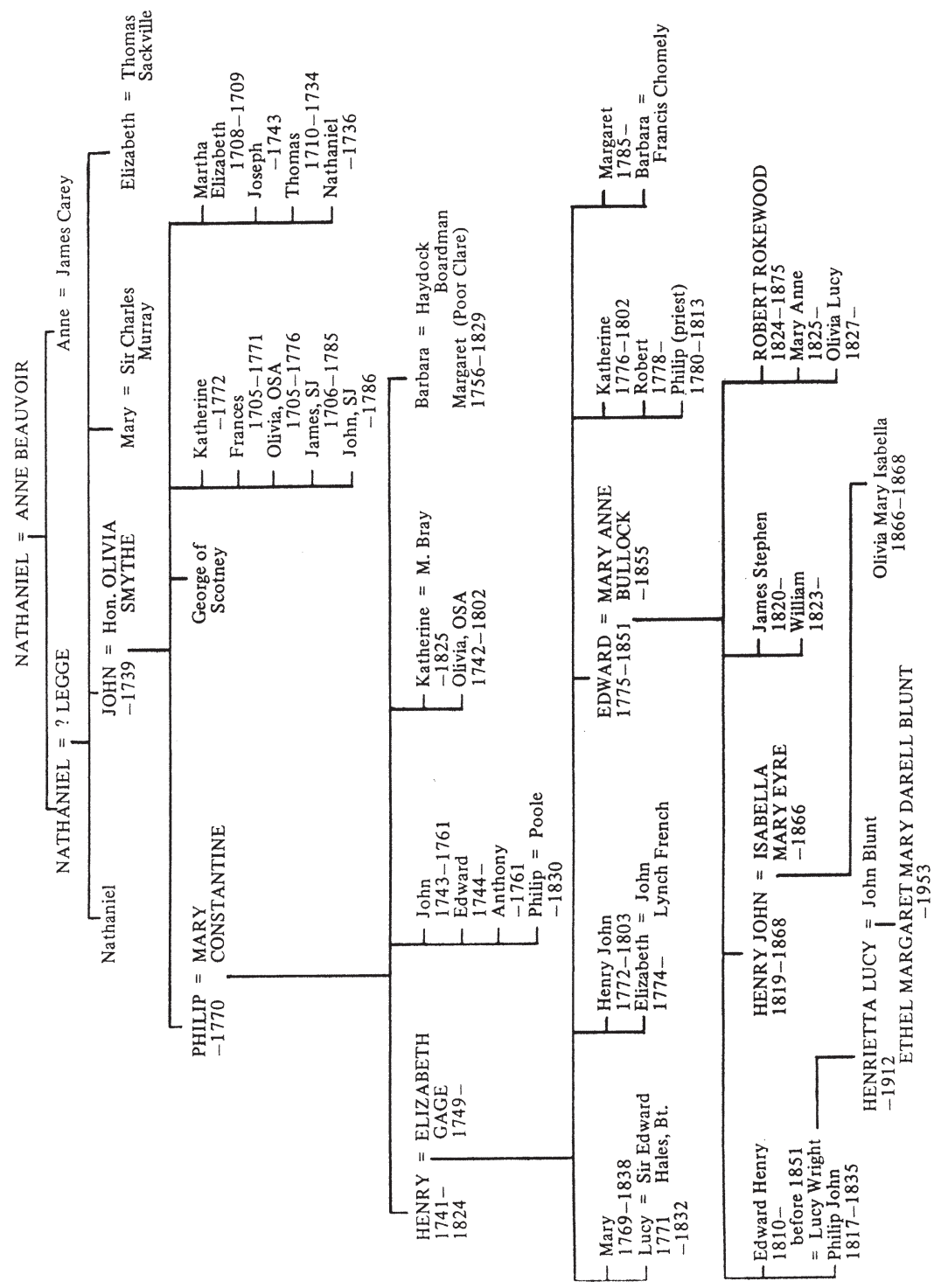


Elizabeth's first appointments as bishop of Winchester; he was notoriously anti-Catholic. Their daughter, Anna, married her distant cousin George Darell, D.D. Prebendary of Westminster, son of Mary Darell, heiress of Pagham, who had married her cousin Revd. Edward Darell of Scotney. ${ }^{5}$ Thus both the Pagham and Scotney branches had Protestant members.

Sir John of Calehill, who succeeded his father in 1583 and died in 1618, was a trustee of Justinian Champneis of Hall Place, Bexley and was unwilling for him to derive any benefit from the trust if he was brought up by his mother, who was a Catholic. Justinian, however, married Sir John's daughter Sarah in $1602,{ }^{6}$ and the families remained in close contact. Sir John's grandson, another Sir John, showed equally clear Protestant sympathies by leaving 'to the Church of Little Chart a silver flagon value $£ 20$ or thereabouts for the more decent administration of the Holy Sacrament of the Lord's Supper" — not a way a Catholic would have described the sacrament.

There is no record of the Calehill family being cited or paying fines as recusants. They do not appear in the lists of Catholics in Kent in 1678, nor were they among those to be granted indulgence under letters of James II in 1685. On the contrary, each head of the family for the 160 years between the Reformation and 1694 was knighted and held public office suitable to his rank. For instance, Robert Darell was in charge of trained bands of the Calehill Hundred in $1608,{ }^{8}$ Sir John was High Sheriff in $1669,{ }^{9}$ and his son and successor, another Sir John, was Deputy Lieutenant in $1689 .{ }^{10}$

\section{Catholic Connections}

On the other hand, there certainly are pointers to Catholic sympathies of some members of the family and some were recusants. A Thomas Darell, native of London, was one of the party of Oxford men who joined Dr. William Allen in founding Douai in $1568 .{ }^{11}$ A Robert Dorrell of Kent appears on a list of 'Catholickes in Inglond' $1574 .{ }^{12}$ There is no Robert of suitable age in the Calehill pedigree, but he could have been a member of a junior branch of the family in Kent: for instance James, the third son of John and Anna had a son Robert who died in 1668. He would have been too young, but there may well have been a Robert in an earlier generation. The provenance of this list is unknown, but it seems to be accepted that it was not an official census but a private list, possibly of people thought to be favourable to Mary Queen of Scots. ${ }^{13}$ It is even suggested in a note in C.R.S., Vol. 13, that George Darell of Calehill may have been intended. The whole family had conservative tendencies and as such he could have favoured Mary without being a convinced Catholic. This is one of the intriguing puzzles to which we are unlikely to find the answer. Another Darell whose identity is mysterious is a John of Sussex included in a list of "principle receivers of 
priests' about London in $1586 .{ }^{14}$ The contemporary John of Calehill seems unlikely, with a wife the daughter of a very Protestant Bishop, and there is no John in the Scotney pedigree at that time. Most surprisingly, Darells are included among those who 'openly espoused foreign attack for the Catholic cause' in $1593 .{ }^{15}$ In 1597 Mistress Dorrell (Darell) was allowed to go to her home in Kent (i.e. Scotney in Sussex) during the delivery of her child despite the fact that she and her husband and servants had been taken into custody for harbouring priests and possibly treasonable words. ${ }^{16}$ Perhaps one of her children was the Richard Darell (alias Fowler) of Scotney who said when he went to the English College in Rome in 1613 that 'my relations on my father's side are Protestants excepting only his sisters; but on my mother's side are mostly Catholics' ${ }^{17}$

The Pagham and Fulmere branches were evidently similarly divided, some having been Anglican parsons, as we have already noted, while others became Jesuits or Blue Nuns of Paris in the seventeenth century.

\section{A Church-Papist Darell}

There was another member of the Darell family who epitomised the 'Church-Papist' position. He was William Darell, who was instituted Rector of Little Chart in 1546 and held the living until 1560, when he became chaplain to Queen Elizabeth I and sub-Dean of Canterbury. ${ }^{18}$ He held the living of Benenden in $1561,{ }^{19}$ having been appointed by the Guldefords, who owned the advowson, who were Catholic relations of the Darells. He was Chancellor of Bangor 1565-1570 and Prebendary of Lichfield 1568. In 1579, however, the Privy Council ordered Canterbury Ecclesiastical Commission to investigate allegations against William Darell, one of the canons 'and an elderly conformist Catholic'. ${ }^{20}$

The appearance of Darell names in these lists indicates that at least some members of the family had Catholic sympathies of which the authorities were aware. These Catholic connections may account for the restriction imposed on Robert Darell, son of Sir John Darell of Calehill in 1634, when he was given a licence to travel abroad 'provided he repairs not to Rome'. ${ }^{21}$

\section{Conservative and Royalist}

The Calehill Darells were conservative in politics. Sir George opposed Wyatt's rebellion. ${ }^{22}$ Sir Robert was active in preliminaries to Parliamentary elections under Charles I; his house was ransacked by Parliamentarians and his wood spoiled of timber. ${ }^{23}$ His son, Sir John, was in Oxford with the King in 1643-4, but returned to Calehill with a safe-conduct from Fairfax in 1648, and in 1655 a fine of £101:9:0 for delinquency (i.e. support of Charles I) was imposed on him by Parliament. ${ }^{24}$ 


\section{Return to Catholicism}

While the senior members of the family were occupied by the Civil War, a younger brother of Sir Robert, Nathaniel (born 1578, died 1650), became Lieutenant Governor of Guernsey. ${ }^{25}$ He married Anne of Beauvoir, of an old Guernsey family and almost certainly a Protestant. ${ }^{26}$ Their son, Nathaniel, became Governor of Sheerness and of Landguard Fort. He married a daughter of Sir John Legge, a staunch Catholic. Her sister was one of the first Benedictine Nuns at Dunkirk, professed in 1666. Presumably because of his marriage he was denounced as a Papist. He refuted the charge to Lord Arlington, Secretary of State. ${ }^{27}$ In 1683, Sir John Darell apparently realised that the heir to the estate, John, was son of the Nathaniel who had married a Catholic and that he was being brought up by his mother. He attempted to ensure that he would not be brought up by her, in exactly the same way as Sir John Darell had attempted with Justinian Champnies in a previous generation. By 1693, just before his death he had given up the attempt and, on his death, John Darell inherited Calehill. ${ }^{28}$

\section{John and Olivia}

John Darell married Olivia Smythe, second daughter of Philip, 2nd Viscount Strangford of Co. Down in the peerage of Ireland, descended from Sir John Smythe of Osterhanger (Westerhanger, Kent). Her mother was Mary, daughter of George Porter, Groom of the Bedchamber to James II. ${ }^{29}$ The Strangfords and Porters were Catholics and by about 1705 the Darells of Calehill were known as Catholics. They appear in a list of families who were known to keep chaplains, drawn up at about that time. ${ }^{30}$ John Darell complied with the laws requiring Catholics to register their lands in $1731 .^{31}$ Henry Darell and his uncle James (Fr. James Darell, S.J.) signed the oath of allegiance to George III in 1778 under the Catholic Relief Act. ${ }^{32}$ In 1789 Mr. Darell was charged with 'double land tax in proportion with others,, 33 in accordance with the penalties on Catholics remaining at that time.

The Darells maintained close connections with the Jesuits over several generations. In 1598 Scotney Castle had been the scene of the famous escape of Fr. Richard Blount from the searchers and the story of his escape was told by one of the Scotney Darells, the Rev. Richard. A hundred and eighty years later, Fr. John Darell, S.J. of Calehill, writing to his brother at Scotney, remarked what a good understanding there had been between Darells and Jesuits throughout that time. ${ }^{34}$ John and Olivia sent six sons to be educated at St. Omers. ${ }^{35}$ They were able to obtain some help with the fees from a free place which had been endowed there by a relative of Olivia, either her sister's mother-in-law, Lady Audley, or Lady Audley's second husband, Colonel Charles 
Porter. Two of their sons became Jesuits; Fr. John (1750-1768) was Rector of St. Omers when the Jesuits were dispossessed by the French in 1762 and he managed to arrange the safe removal of all the boys to Bruges. He returned to England and served the mission at Wealside, home of the Wright family. He died in London. He was said to be admired by 'all visitors to the famous seminary for the polished urbanity of his manners and considerate hospitality'. ${ }^{36}$ His brother James (17061785) took a party from St. Omers to revive the college at Valladolid in the 1730's and then was at Broughton with Mr. Stephen Tempest until 1739. Afterwards he was in London and, for a number of years towards the end of his life, he was chaplain to his nephew Henry at Calehill. ${ }^{37}$ Another brother, Thomas (1711-1734) entered the Society, but died as a scholastic. ${ }^{38}$ John and Olivia also had five daughters, one of whom, named Olivia, entered the Augustinian convent at Bruges in 1734 when she was 29 and died there in 1776. John's second son, George, inherited Scotney under his cousin's will when the estate would otherwise have been left to four sisters, and his possession was confirmed after a lawsuit by the sisters.

\section{Philip and Mary}

On John's death in 1739 Calehill passed to his eldest son, Philip, who had married Mary Constantine of an old Dorset Catholic family. ${ }^{39}$ They were married by special licence from the Archbishop of Canterbury without banns. ${ }^{40}$ Three of their five sons were certainly educated at St. Omers. ${ }^{41}$ Two of those five had military careers with foreign armies and two of their four daughters entered convents: Olivia, or Mary Olivia, followed her aunt into the Augustinian convent at Bruges in 1757 and died there in 1802; the youngest daughter, Margaret, was professed at the house of the English Poor Clares at Gravelines in 1816, when she was 60, and died there in $1829 .^{42}$

In taste and style Philip was evidently a country gentleman of the nineteenth century. The Calehill house which he had inherited, probably a Tudor adaptation of the medieval house rebuilt by John Darell after his purchase in 1410, was pulled down in 1753 and a large Georgian style mansion erected in its place. A plan among the family papers shows a wide front of three groups of three windows and a chapel building at one side balanced by a laundry building at the other. Stables are all that remain, but, even they, according to Pevsner, are 'for stables, decidedly grand'. ${ }^{43}$

\section{Henry and Elizabeth}

Philip's eldest son, Henry, succeeded his father in 1770. He had married Elizabeth, daughter of Thomas Hookwood Gage of Coldham, Suffolk. ${ }^{44}$ 
It is known that one of their four sons, Philip, was educated by the Jesuits, first at Liège and then at Stonyhurst; ${ }^{45}$ probably therefore the rest of Henry's sons were similarly educated. The son Philip became a secular priest in 1812 but died in Preston the following year after ministering to the victims of an epidemic. The family erected a tablet in St. Wilfrid's Chapel 'where his eloquence must have electrified the hearts and minds of his hearers'. Four of Henry's daughters were educated by the Canonesses of the Holy Sepulchre at Liège; ${ }^{46}$ presumably the fifth was also sent there. None of them became nuns; Lucy married a near neighbour, a Catholic, Sir Edward Hales, of Hales Place, Hackington, and two others also married. ${ }^{47}$ Henry seems to have lived at Liège for a time in the 1780s. His youngest daughter, Margaret, was baptised there in 1785 and his uncle and chaplain, James Darell, S.J., died there in the same year. $^{48}$ There is no indication why he stayed in Liège. He evidently returned to Calehill and in 1798 sought Counsel's opinion on his right to hunt over all the land on which quit rents were payable to him. Mr. Serjeant Hill advised that he had no such right ${ }^{49}$ - but the question suggests where at least one of his main interests lay. He was buried at Calehill in 1824.

\section{Edward and Mary and their descendants}

As Henry's eldest son, Henry John, died in India in $1803,{ }^{50}$ his second son, Edward, inherited Calehill. His wife was Mary Anne Bullock of Yorkshire, whose uncle, Thomas Bullock, O.P., was chaplain at Calehill intermittently until his death there in 1819. He was twice Provincial of his order. ${ }^{51}$ Like his older brother, Edward had served in India before his marriage, and was given permission to return to England in 1802 by the Governor of Ceylon with a testimonial to his conduct as Commissionary of Ordnance. ${ }^{52}$

$\mathrm{He}$ and his wife went on the Grand Tour after their marriage. They showed some interest in reading as they both obtained permission from the Pope to read books from the forbidden list-'de sua magna erudizione'. ${ }^{53}$ The family papers contain an index of the books in the library at Calehill in $1856 .{ }^{54}$ There were the classics of Latin and French literature and a certain number of English writers like Smollett, Hazlitt, Byron, Chaucer, and Dr. Johnson; a good many books on history and travel, including a life of Cardinal Pole and Lingard's History of England, and also a Douai Bible. There was a dearth of books of devotion or apologetics in the list, but perhaps they would not be kept in the library.

Edward seems to have given up living at Calehill house before he died, as a newspaper obituary, in the late Fr. Leonard Whatmore's possession, of an old servant of the family, in 1849 states that she 'remained in the service of succeeding generations at the great house as long as they 
resided there.... He was, however, evidently keen that the house and contents should be preserved and a codicil to his will, dated 18th December 1850, left legacies to a number of distant relations and also provided that a number of portraits and pictures should be made heirlooms. ${ }^{55}$ They were all sold after the death of Miss Ethel Darell Blunt, the last of the line, in 1953.

Edward died on 13th January 1851. His eldest son, Edward Henry was evidently dead, ${ }^{56}$ and his second son, Philip John, had died of cholera in Algiers in $1835 .{ }^{57}$ Calehill therefore passed to Henry John. He had been commissioned as a Captain in 1847 but was subsequently living in Rome. ${ }^{58}$ Apparently Calehill was dilapidated and mortgaged by that time. In 1865 Henry John married Isabella Mary Eyre of Linley Hall, Leicestershire, but she died the next year and Henry John and his daughter died two years later. ${ }^{59}$ Two other sons of Edward were already dead, so the sixth son, Robert Rokewood held Calehill until his death in $1875 .{ }^{60}$ He was succeeded by his niece, Edward Henry's daughter Henrietta Lucy, wife of John Blunt of Mapledurham, who assumed the name of Darell-Blunt. ${ }^{61}$ In 1912 her daughter, Ethel Margaret Mary DarellBlunt succeeded to Calehill on her mother's death and she sold the family home to Mr. Chester Beatty in 1913. In the 1950's she was living at Holly Cottage, Heron's Ghyll, Sussex and corresponding with one of the Servite fathers in Uckfield, Sussex. ${ }^{62}$

The house itself was demolished by Chester Beatty's son in the 1950's: the Darell family, however, still own the vault beneath the ruined aisle of the bombed church of Little Chart. Twenty-six Catholic members of the family and their connections are buried there. ${ }^{63}$

There was a privileged altar in the chapel at Calehill; the document authorising it is now at the church at Ashford. The carved pews from the chapel have found their way, through the late Fr. Whatmore's good offices, to the Catholic Church at Wye. There were also some good pictures in the chapel, a Correggio and two Carlo Dolcis. These were presumably the pictures mentioned in the codicil to Edward Darell's will in 1850; the death of Joseph, Ecce homo, and a Madonna. They were probably at one time in the presbytery at Ashford, but have now disappeared. ${ }^{64}$

The numbers attending the chapel at Calehill house remained between forty and fifty for the whole eighteenth century. ${ }^{65}$ It was licenced as a place of worship under the Catholic Relief Act in $1792 .{ }^{66}$ From Calehill a Mass Centre was established in Ashford in 1854 and ten years later the parish was established there, but Calehill continued to be a Mass Centre until $19300^{67}$

Dr. Burton may have been mistaken in claiming that the Calehill Darells were always Catholics, but his mistake is easily understandable. Throughout the eighteenth and nineteenth centuries they were one of the leading Catholic families in Kent, and, for much of that period, they 


\title{
provided one of the four Mass Centres, which were all that existed in the entire county.
}

\section{ABBREVIATIONS}

\author{
C.R.S. \\ Foley \\ Catholic Record Society Publications (Records Series). \\ K.A.O. \\ H. Foley, Records of the English Province of the Society of Jesus (Burns \& Oates, \\ London, 1877-83, 7 vols). \\ Recusancy \\ Kent Archive Office, Maidstone. \\ U.386 \\ L. M. Whatmore, Recusancy in Kent, Studies and Documents (privately printed \\ 1973). \\ Kent Archive Office, Darell collection.
}

\section{NOTES}

Recusant History, Vol. 12, No. 4, p. 157 (1973-4).

2 U.386/F.8.

3 Camden Society, Letters from the Bishops to the Privy Council, 1564. ed. Mary Bateson, Camden Miscellenany, Vol. 9, 1895. 3rd article dated London 1893, separately paginated, i. Geo. Darell p. 58. ii. Return of Chichester re Gage and Culpepper, p. 10 (Matthue Cantnas did not return any 'unsuitable' names).

4 U.386/F.8. E. H. Burton, Life and Times of Bishop Challoner, Vol. 1, p. 195.

5 U.386/F.8.

6 U.386/F.8. Archaeologica Cantiana, Vol. 18, p. 370.

7 U.386 T109/8.

$8 \quad$ U.386 03.

9 U.386 03/4.

10 U.38603.

11 M. Guilday: English Catholic Refugees on the Continent 1558-1795 (London, 1914). p. 65.

12 C.R.S. v. 13, pp. 86-138.

13 W. R. Trimble, Catholic Laity in Elizabethan England (Bellknap Press (Harvard) 1964) p. 69. State Papers, 12/99/55 (1574).

14 J. Morris, The Troubles of our Catholic Forefathers (London, 1875) 2nd series, p. 158.

15 Peter Clark, Religion, Politics, and Society in Kent, 1500-1640 (Hassocks, Sussex, 1977), p. 158.

16 Trimble, op. cit., p. 157.

17 Foley, Vol. III, p. 476.

18 C. W. Field, The Province of Canterbury and the Elizabethan Settlement (Robertsbridge, Sussex, 1973), p. 31 .

19 Kent Recusant History, Vol. 3, p. 60.

20 Archaeologica Cantiana, 1974, p. 186 (P. Clark, Ecclesiastical Commission of Canterbury, 1572-1603).

21 U.386 08/4.

22 Peter Clark, op. cit., p. 89.

23 A. M. Everitt, The Community of Kent and the Great Rebellion (Leicester Society Kent Records, v. xxix, 1966), pp. 71, 114 and 170.

${ }^{24}$ U.386 08/1.

25 Fr. L. Whatmore papers.

26 Letters from Guernsey authorities.

27 U.386 F.8; Foley, Vol. III, pedigree between pp. 476 and 477.

28 U.386 F.8; Fr. L. Whatmore papers and Southwark Record August 1950. Kent Recusant History Nos. 12 and 13. (Autumn 1984 and Spring 1985) p. 222. Mr. Darell's Case: 12th and 13th June 1683. Sir John Darell Kt. Left his estate to John Darell his kinsman for life provided he gave up the Catholic education by his mother and other relations and came under the Protestant upbringing of Justinian Champneys. If not, J. Champneys to have use of the estate for life and in trust for J. Darell and others to whom the remainder falls in their respective times... 16th June 1693. Sir John revokes the previous settlement. A. changes J. Champney's use of the estate to 10 years, B. gives J. Darell $£ 50$ a year for the ten years out of his lands in the settlement, $C$. gives all his estate after the ten years to John Darell without any of the previous conditions, then to his first and other sons in tail male, then to Robert Darell (who has since died s.p.) etc.... John Darell about next Michaelmas will be 21 and going to his mother and relations in Oxfordshire (i.e. the Legges). Wants a copy of the last deed. J. Champneys directed him by letter where he might have a copy. (Question 1) There follows an opinion in a Francis Pemberton's handwriting that he thinks Sir John Darell made a 'new absolute devise' when he revoked previous settlements without conditions annexed. (Question 2) If the condition is not recognised as 
revoked will John D. have to prove he fulfilled it, or what can he do in the meantime before coming of age to help his case. (Answer to Question 2) I think (as before) that the condition is now out of the case. But if it should be thought a conditional estate to John for life yet if Mr. Champneys never took upon nor attempted to take upon him the education of John Darell nor any ways interrupted or hindered from having the education of Mr. Darell by his mother or any of his relations nor Mr. Darell himself never refused to be educated by him but barely was not educated by him because Mr. Champneys never took upon him the education of him this will not be such a breach of the condition as will forfeit the estate.

29 L. E. Whatmore, Southwark Record, September, 1952.

30 Recusant History, Vol. 12 (1), p. 47.

31 K.A.O., $Q$ RR, p. 11

32 K.A.O., Q.

33 U.386 E.23 1-3.

34 Foley, Vol. III, p. 452; U.386.

35 C.R.S., Vol. 62, pp. 5, 144; C.R.S., Vol. 69, pp. 82-83.

36 Foley, Vol. VIII, pt. 1, p. 194; Vol. III, p. 477.

37 C.R.S., Vol. 30; Foley, Vol. VII, p. 194; C.R.S., Vol. 32.

38 C.R.S., Vol. 69, p. 83 .

39 U.386 F.8.

40 U.386 F.8.

41 C.R.S., Vol. 69, p. 82; U.386 F.8.

42 Foley, Vol. III, p. 479; C.R.S., 1914, p. 163.

43 U.386 E.3/1-2; N. Pevsner, West Kent and the Weald (Penguin Books, London, 1969), p. 368

44 U.386 F.8; L. E. Whatmore, Southwark Record, September, 1952.

45 Foley, Vol. III, p. 479.

46 C.R.S., Vol. 17, p. 162.

47 U.386 F.8; Recusancy, p. 32.

48 U.386 F.8; Foley, Vol. III, p. 478, Vol. IV, p. 267.

49 U.386 E.25.

50 C.R.S., 12 , p. 90 .

51 U.386 F.8; C.R.S., Vol. 16, p. 214; Recusancy, p. 56 (Whatmore calls him John).

52 U.386 $04 / 1$.

53 U.386 F.9.

54 U.386 E.6.

55 U.386 109/15.

56 Recusancy, p. 57.

57 U.386 F.8.

58 U.386 04/2; (ed.) L. E. Charlton: Recollections of a Northumbrian Lady (Cape, London, 1949), p. 282.

59 U.386 F.8; Recusancy, p. 57.

60 Ibidem.

61 U.386 F.6/1.

62 U.386 F.8; Recusancy, p. 57.

63 Recusancy, p. 55.

64 Ibidem, p. 58; verbal information from the late Fr. Whatmore.

${ }^{65}$ H. E. Burton, Life and Times of Bishop Challoner (London, 1910), pp. 195-201.

66 U.386 02/4.

67 Recusancy, p. 57. 